\author{
Andrzej Juchniewicz \\ Uniwersytet Ślaski w Katowicach \\ (iD https://orcid.org/0000-0001-7037-9907
}

\title{
Poeci i ich zwierzęta
}

\section{Poets and Their Animals}

Abstract: Anita Jarzyna's essays, collected in the book Post-koiné. Studia o nieantropocentrycznych jezykach (poetyckich) (Post-Koiné. Studies on Non-Anthropocentric (Poetic) Languages), contribute to the flourishing field of animal studies. Her work develops a coherent theory of the reading of poetry using the latest methodologies. Jarzyna's main argument, developed through a microscopic analysis of the the poems of several dozen poets, is for the necessity of the intentional reconfiguration of well-worn expressions and the re-evaluation of tropes. The reason for this is, as Donna Haraway argues, that such linguistic constructions and tropes are the reason the language "deviates from the correct path and takes a turn". This remark applies not only to the works of Joanna Mueller and Justyna Bargielska, which intercept and neutralise derogatory language related to hunting (pomiot, pokot), but also to poets deconstructing oxymorons functioning in the Polish language (as in the case of Ryszard Krynicki), as well as allusively referring to canonical formulas (Adorno) which are of importance in the period (for example, in the poems of The Lives of Birds and Mammals, Kronhold). This is not the only strategy Jarzyna decides to pursue. She also outlines a complementary account of the animal biography (for example, Laika the dog, one of the first animals in space), the publicizing of which is part of Éric Baratay's project of extending human history to non-human actors. The French historian postulates that the animal cannot remain a blank spot in history; a methodology for reading documents and testimonies must be developed in order to allow the reconstruction of the life path of animals. In the light of new research, the agency of animals is unquestionable, a narrative that Jarzyna also builds upon. This project criticizes many stereotypes and announces the development of a new way of speaking and thinking about writing. The first step in revising the old order is to revolutionize language by purifying it of animal-related curse words and other linguistic constructions that harm animals. In the eyes of this reviewer, Jarzyna's monograph stands out from 
other publications in terms of the construction of the argument and its central premises, which go beyond the cautious style of many academic books.

Key words: Polish contemporary poetry, animal studies, eco-activism, naturocentrism, violence against animals

Streszczenie: Studia Anity Jarzyny zebrane w książce Post-koiné. Studia o nieantropocentrycznych językach (poetyckich) lokują się w polu "przeżywających” obecnie rozkwit studiów nad zwierzętami i wypracowują spójną koncepcję czytania poezji z zastosowaniem najnowszych metodologii. Pomysł Jarzyny, która poddała mikrologicznej analizie wiersze kilkudziesięciu poetek i poetów, oparty jest na śledzeniu intencjonalnych rekonfiguracji utartych wyrażeń i dowartościowaniu tropów, ponieważ, jak przekonuje Donna Haraway, to one powodują, że język „odchyla się od właściwego kursu i skręca”. Uwaga ta odnosi się nie tylko do twórczości Joanny Mueller i Justyny Bargielskiej, które przechwytują i unieważniają inwektywy łowieckie (pomiot, pokot), lecz również poetów dekonstruujących funkcjonujące w polszczyźnie oksymorony (casus Ryszarda Krynickiego), a także aluzyjnie nawiązujących do kanonicznych formuł (np. Adorna), których znaczenie ulega rozszerzeniu (casus wiersza Życie ptaków i ssaków po Kronholda). Nie jest to jedyna strategia, na jaką decyduje się Jarzyna. Zarysowuje też komplementarną narrację o zwierzęcych biografiach (np. Łajki), których nagłaśnianie wpisuje się w projekt poszerzania ludzkiej historii o nieludzkich aktorów, autorstwa Érica Barataya. Francuski historyk postuluje, że zwierzę nie może być nadal białą plamą historii, dlatego należy wypracować koncepcję czytania dokumentów i świadectw, która pozwoliłaby na zrekonstruowanie losu zwierząt. Ich sprawczość jest w świetle nowych badań niepodważalna, co podkreśla również Jarzyna. Jej projekt poddaje krytyce wiele stereotypów i zapowiada wypracowywanie nowego sposobu mówienia i myślenia o zwierzętach. Pierwszym etapem rewizji starego porządku ma być rewolucja języka i oczyszczenie go z inwektyw o podłożu animalnym i porównań, które zawsze pozostają krzywdzące dla zwierząt. W ocenie autora tekstu monografia Jarzyny wyróżnia się na tle innych publikacji sposobem prowadzenia wywodu i narracją, która wykracza poza kostyczny styl książek akademickich.

Słowa kluczowe: polska poezja współczesna, studia nad zwierzętami, ekoaktywizm, naturocentryzm, przemoc wobec zwierząt

Zwierzęta nie są w stanie zachować się tak podle jak ludzie.

D. Gzyra: Dziękuję za świńskie oczy. Jak krzywdzimy zwierzęta

Biopoetyka opiera się na założeniu, że zmienić należy nie definicję natury, lecz definicję człowieka - bo 
to wyobrażenia antropologiczne decydują o całej reszcie. Człowiek zachowuje się w świecie tak, jak dyktują mu to przekonania o swoim człowieczeństwie - przekonania o przywilejach i obowiązkach wobec reszty istnienia, o podobieństwach i różnicach wobec innych istot.

P. Czapliński: Literatura i życie. Perspektywy biopoetyki

Kiedyś planeta pogrąży się w mokradłach, podmokłe lasy będą parować gnijącym słodkim zapachem, stare książki z papieru będą dryfować w miękkim krople brudnej wody utworzą gorącą mgłę. bagnie, Nad brzegiem będą maszerować nowe istoty: ciągle

podobne do naszych krów, ziemskie, bo ostatecznie tylko łagodne rzeczy mogły

łagodne, spokojne, prawie refleksyjne.

przetrwać:

M. BIELSKa: Hen po zagładzie

Ze względu na wciąż zmieniające się podejście do kwestii ochrony środowiska ${ }^{1}$, interferowanie pierwiastków: zwierzęcego, ludzkiego i cyborgicznego, które naznaczyły obcością każdą z wymienionych ontologii i pogrzebały wiarę w autonomiczność człowieka², oraz fakt, że wyniki badań przedstawicieli animal studies ${ }^{3}$ wywarły wpływ na

1 S. Łubieński: Ksiażka o śmieciach. Warszawa 2020.

2 Przemysław Czapliński pisze: „Tym, co najmocniej odróżnia go [postczłowieka - A.J.] od człowieka nowoczesnego, jest nieautonomiczność: postczłowiek nie istnieje ani sam, ani samodzielnie - jest częścią (zwierzęco-maszynowo-ludzkich) kolektywów ontologicznych, dzięki którym i w których funkcjonuje. Trzeba patrzeć na człowieka z perspektywy zwierzęcia, cyborga i maszyny, aby zobaczyć inną demokrację. Trzeba ćwiczyć nie-ludzkie myślenie, aby zrozumieć przemiany ludzkiego". IDEm: Literatura $i \dot{z} y c i e$. Perspektywy biopoetyki. W: Teoria - literatura - życie. Praktykowanie teorii w humanistyce wspótczesnej. Red. R. NyCZ, A LegeżyŃsKa. Warszawa 2012, s. 87.

${ }^{3} \mathrm{Na}$ rodzimym gruncie tę nową interdyscyplinarną dziedzinę anonsowała monografia zbiorowa Zwierzęta i ludzie. Red. J. Kurek, K. Maliszewski. Chorzów 2011, a także przywołany wcześniej artykuł Przemysława Czaplí́skiego: Literatura $i \dot{z}$ ycie. Perspektywy biopoetyki, zamieszczony w książce z 2012 roku, inicjującej serię Nowa Humanistyka. Warto wymienić również monografię zbiorową Zwierzęta $i$ ich ludzie. Zmierzch antropocentrycznego paradygmatu. Red. A. BARCz, D. ŁagodzKa. Warszawa 2015. Animal studies szeroko komentowały i implementowały na grunt polskiego literaturoznawstwa książki: A. BARCz: Realizm ekolo- 
sposób postrzegania zwierząt i ich historii, która dotąd pozostawała niewidoczna, studia nad zwierzętami należy uznać za jedną ze strategii kultywowania „produktywnego dyskomfortu”4. Dariusz Gzyra, tłumacząc ten koncept, powołuje się na Rasmusa Simonsa, który łączył go z praktykami wegańskimi:

To uczucie jest dla weganizmu fundamentalne. Kierowane jest ku produktom i praktykom związanym z krzywdą zwierząt, a jego kultywowanie prowadzi do ich konsekwentnej negatywnej oceny. Można jednak powiedzieć, że podtrzymywanie tego dyskomfortu i jego produktywność wiążą się także ze stałym poczuciem niezadowolenia z zakresu pozytywnych zmian i podejrzliwością wobec definicji sukcesu. Przyjęcie lub przynajmniej szczera próba przyjęcia punktu widzenia zwierzęcia, osądzenie z punktu widzenia zwierzęcia gwarantują takie poczucie ${ }^{5}$.

Pytając o to, czy można „zrobić dla zwierząt coś innego, niż próbować na przykład - w boleśnie niewielkim stopniu - reformować szowinistyczne prawo szowinistycznego państwa, zamieszkanego przez większość, która swymi praktykami, przekonaniami i obojętnością karmi ten szowinizm codziennie i z przyjemnością, bez świadomości możliwości zmiany - siebie i otoczenia?"6, Gzyra odpowiada w sposób obrazowy i zarazem kluczowy dla publikacji z obszaru animal studies:

[...] możemy - reformować je [prawo - A.J.] tak, jakbyśmy robili to pod czujnym okiem zwierzęcego sądu, który pilnie słucha i zapisuje, co robimy i jak mówimy. Nieważne, że go nie ma i nie będzie. Trzeba zapomnieć, że zwierzęta nie będą nawet w stanie spojrzeć na nas z wyrzutem; będą umierać i zwijać się z bólu i nikt nas nie rozliczy z tego, jak zareagowaliśmy ${ }^{7}$.

Sposoby mówienia o zwierzętach (jak również sfera działań na ich rzecz) obejmują nie tylko sytuacje codzienne, nieoficjalne, lecz rów-

giczny. Od ekokrytyki do zookrytyki w literaturze polskiej. Katowice 2016; J. FIEDonczuk: Cyborg w ogrodzie. Wprowadzenie do ekokrytyki. Gdańsk 2015; J. FiedorczuK, G. Beltrán: Ekopoetyka. Ekologiczna obrona poezji. Warszawa 2015.

${ }^{4}$ D. Gzyra: Dziękuję za świńskie oczy. Jak krzywdzimy zwierzęta. Warszawa 2018, s. 305.

${ }^{5}$ Ibidem, podkr. - A.J.

${ }^{6}$ Ibidem.

7 Ibidem. 
nież dotyczą uobecniania zwierząt $\mathrm{w}$ literaturze, która, jak dowodzi Anna Filipowicz, stanowi lekcję krytycznego myślenia, a także ćwiczenie z empatii i odpowiedzialności ${ }^{8}$. Najważniejszym zadaniem literatury, która stawia sobie za cel reprezentację zwierząt, jest komplementarność autorskich rozwiązań i intencji, jakie niewątpliwie poprzedzają każdy akt pisania: „To, że zwierzęta nie mówią same w swoim imieniu tak, że większość potrafiłaby je zrozumieć i potraktować poważnie, nakłada ogromną odpowiedzialność na wszystkich tych, którzy starają się być ich rzecznikami"' . Przywracanie zwierzętom należnej im pozycji przebiega dwutorowo: demontażowi ulega utrwalona retoryka, której podstawową regułą jest lokalizowanie zwierzęcości w polu tego, co złe, odrażające, instynktowne, niskie, oraz dostrzeganie mikrokosmosu tych gatunków, które zajmowały „dolne rejony hierarchii stworzeń"10 (m.in. gołębie), a także biografii zwierząt związanych z człowiekiem siecią przygodnych relacji.

W ostatnich latach doszło do odrzucenia antropocentrycznego wzoru historiografii, zaakcentowania unikalności zwierzęcych dziejów, a także zrekonstruowania (na ile było to możliwe) losów poszczególnych gatunków (podkreślając przy tym niesprzyjające warunki bytowania zwierząt, zrównanie ich martwych ciał z odpadem, brak opieki weterynaryjnej), które odegrały kluczową rolę w XIX- i XX-wiecznej historii1 ${ }^{11}$ ze względu na swoje umiejętności, zakładaną przez człowieka ad hoc nieistotność i odwagę, która przekracza zdroworozsądkową kalkulację człowieka. Éric Baratay, rekonstruując losy zwierząt frontowych, pisze:

[...] mowa o żywej istocie, która czuje, doświadcza, przystosowuje się, działa. Nie chodzi o to, aby przyjąć zwykłą postawę otwierającą na przyjemne ćwiczenie intelektualne, które byłoby wymuszone, infantylne i czcze, ale o przekonanie będące fundamentem innego rozumowania. Opiera się ono na współczesnych naukach (etologii, psychologii, neurologii...), które mnożą znaki zapytania i przypisują zwierzętom coraz większe zdolności oceny i czucia, coraz większe możliwości interpretacji, komunikacji, inicjatywy i adaptacji $1^{12}$.

8 A. Filipowicz: (Prze)zwierzęcenia. Poetyckie drogi do postantropocentryzmu. Gdańsk 2017, s. 46.

9 D. Gzyra: Dziękuję za świńskie oczy..., s 64.

${ }^{10}$ Ibidem, s. 19.

${ }^{11}$ Zob. É. Baratay: Zwierzęcy punkt widzenia. Inna wersja historii. Przeł. P. TARasewicz. Gdańsk 2014; Idem: Zwierzęta w okopach. Zapomniane historie. Przeł. B. Brzezicka. Gdańsk 2017.

12 É. Baratay: Zwierzęcy punkt widzenia..., s. 34. 
Brak możliwości samostanowienia, odgrywanie roli „mięsa

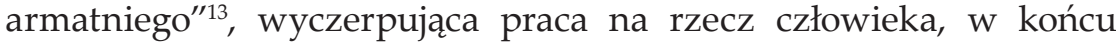
ludzka niewdzięczność, której kres znamionują XX-wieczne formy upamiętnienia nie-ludzkich aktorów, świadków i ofiar Wielkiej Wojny $^{14}$, nie są dostatecznymi argumentami na rzecz obalenia tezy o sprawczości zwierząt i uznania ich wkładu w tworzenie nowych porządków politycznych i potęg gospodarczych. Zwierzęta należy traktować jako aktywnych uczestników dziejów (podobnie jak warunki klimatyczne) ${ }^{15}$, pamiętając o porzuceniu chęci hierarchizacji podmiotów badań i uprzywilejowywania ludzi kosztem przeszłości, doświadczeń i emocji zwierząt.

Badacze reprezentujący obszar studiów nad zwierzętami konfrontowani są z opiniami na temat nieistotności naukowych przedsięwzięć, a także szkodliwości jakichkolwiek działań mających destabilizować hegemoniczną pozycję człowieka. Portal Gosc.pl w sposób protekcjonalny i bez zachowania zasad rzetelności dziennikarskiej zaatakował organizatorów konferencji "Zwierzęta i ich ludzie. Zmierzch antropocentrycznego paradygmatu?":

Nie mamy nic przeciw badaniom zjawiska „uczłowieczania” zwierząt. Jednak takie zdefiniowanie pola badań, jakie prezentują organizatorzy konferencji (najwyraźniej widać to w sposobie sformułowania wytłuszczonych wyżej zagadnień), sugeruje coś więcej niż chłodne podejście naukowe. Już samo nazwanie człowieka przez organizatorów jednym ze zwierząt w niedopuszczalny, z góry akceptujący sposób, ustawia optykę badań ${ }^{16}$.

Dziennikarzy oraz prawicowych komentatorów zaniepokoiły (co również odnotował Gzyra) ${ }^{17}$ słowa klucze („cielesność”, „relacje”,

${ }^{13}$ Ibidem, s. 167-190.

${ }^{14}$ Warto przywołać dwa przykłady świadczące o zmianie stosunku ludzi do zwierząt biorących udział w wojnach i upamiętnianych w formie pomników: w 1996 roku odsłonięto tablicę poświęconą pamięci osłów z Verdun (zlokalizowaną w Neuville-les-Vaucouleurs), zaś w 2004 roku - poległym na wojnie zwierzętom w Couin nad Sommą poświęcono pomnik z dewizą „Nie zapomnijmy o nich".

${ }^{15}$ C.R. Foltz: Czy przyroda jest sprawcza w znaczeniu historycznym? Historia świata, historia środowiska oraz to, w jaki sposób historycy moga pomóc ocalić Ziemię. Przeł. A. Czarnacka. W: Teoria wiedzy o przeszłości na tle wspótczesnej humanistyki. Antologia. Red. E. DomańsKa. Poznań 2010.

${ }^{16}$ Dalej niż gender. Ludzie i inne zwierzęta. https://www.gosc.pl/doc/1874121. Dalej-niz-gender-Ludzie-i-inne-zwierzeta [dostęp: 26.07.2020].

${ }^{17}$ Działacz prozwierzęcy pisze: „Tytuły blisko stu referatów czytali prawdopodobnie tak, jak internauci czytają teksty w sieci - powierzchownie, wyłapu- 
„holokaust”, „prawa zwierząt”), które niewątpliwie zwiastują kres hegemonii człowieka; nowy porządek polegałby na zaprzestaniu obsadzania zwierząt $\mathrm{w}$ roli istot podległych i podporządkowanych. Opinię o zwierzęcej podrzędności umacniają także m.in. Kościół katolicki oraz zrzeszenia myśliwych, kłusowników, a także politycy, forsujący wizję rodzinnych polowań mających walor edukacyjny ${ }^{18}$. Po rekonstrukcji argumentów obrońców „starego porządku” można dodać, że ludzka podatność na bazowanie na stereotypach, szowinizm gatunkowy i zaburzanie proporcji między zasługami przypisywanymi ludzkim aktorom, a ich wadami i niszczycielskimi zapędami to główne przeszkody $\mathrm{w}$ uznaniu doniosłości studiów nad zwierzętami w Polsce.

Kwestia rozszerzenia ram kadru zawsze pociąga za sobą konsekwencje dostrzeżenia działań tych, którzy starają się zafałszować perspektywę i utrzymać status quo zarówno w kwestii antropocentrycznej historiografii, jak i języka pogardy, w którym zwierzęce imaginarium podlega korzystnym dla człowieka przekształceniom i nadużyciom. Stąd opozycja między "ludzkim” i „zwierzęcym”, która jawi się jako monolit i nie podlega, według zwolenników antropocentrycznego porządku, żadnym fluktuacjom i wzajemnym wpływom, a także rozszczelnieniom. „Zwierzęce” zachowania, nawyki pozostają nieczyste, godne politowania, pogardy i przechwycenia jako dotkliwe obelgi, choć, jak podkreśla Gzyra,

To nie one [zwierzęta - A.J.] niewolą innych i nie one odbierają innym życie w rzeźniach. Zbydlęcenie człowieka nie oznacza przejęcia złych cech krów. To, co określa się mianem zbydlęcenia, było i jest ludzkie. A „uczłowieczony" nie jest czymś na kształt ideału, jakim ma być człowiek ${ }^{19}$.

Określenia „suka” i „maciora” nie powinny funkcjonować w ludzkim języku jako inwektywy, podobnie jak leksem „bydło” nie może

jąc słowa klucze. Tu zapłonnikami zainteresowania i reakcji obronnej okazały się sformułowania w rodzaju »cielesność«, »relacje« czy »holocaust«. Nieważne, w jakim dokładnie kontekście występują. Kojarzą się. To wystarczy, żeby podnieść larum i zacząć się bać, a ze strachu bić na oślep". D. Gzyra: Zwierzęta i ich studia. https://krytykapolityczna.pl/kraj/gzyra-zwierzeta-i-ich-studia/ [dostęp: 26.07.2020].

${ }_{18}$ Zob. wystąpienie posła Dariusza Olszewskiego: https://wyborcza.pl/10, 82983,25872896,posel-pis-mysliwi-chronia-zwierzeta-a-rodzinne-polowania-ma ja.html [dostęp 26.07.2020].

19 D. Gzyra: Dziękuję za świńskie oczy..., s. 54. 
charakteryzować grupy ludzi, ponieważ to, co neutralne i obojętne, zyskuje, dzięki człowiekowi, pejoratywny wydźwięk. Gzyra w eseju $W$ poszukiwaniu innego jezzyka postuluje: zaprzestanie używania nazw zwierząt $w$ celach deprecjacji przeciwnika. Zarysowana tu opozycja rozciąga się także na inne sfery ludzkiego życia:

[...] mówienie o umieraniu zwierząt jest językowym błędem. Na podobnej zasadzie ludzie mają cmentarze, zwierzęta grzebowiska. Ludzi się zabija, a zwierzęta ubija. Tylko ludzi można mordować i tylko zwierzęta się usypia, gdy się im odbiera życie. Powszechnie używa się pojęcia ludobójstwa, a „zwierzobójstwo” jest tylko ciekawostką językową z niszowych książek. Starannie maskujemy fakt, że sami jesteśmy zwierzętami. Określamy tak tylko tych ludzi, którym brakuje tak zwanego człowieczeństwa, rozumianego oczywiście jako zespół pozytywnych cech ${ }^{20}$.

Argumentem za podtrzymaniem przez człowieka różnicy między nim a zwierzętami ma być także redukowanie wszelkich odczuć psychicznych tych ostatnich, reakcji na niebezpieczeństwa, a także psychosomatycznych objawów, świadczących o czulszym niż wydawało się człowiekowi do tej pory sondowaniu rzeczywistości i podatności na wydarzenia traumatyczne:

[...] fizjologiczna bliskość wspomnianych trzech gatunków [bydła, koni, psów - A.J.] i człowieka - przede wszystkim obecność rozwiniętego, złożonego układu przewodzenia bólu, z włóknami i substancjami, skonstruowanego i funkcjonującego $\mathrm{w}$ ten sam sposób, oraz kory nowej - uprawomocniają tezę, że ich ból i cierpienie są rzeczywiste, podobne, równe ludzkim, a nie mniejsze. Do tego stopnia, że sposoby wyrażania ich okazują się podobne $\mathrm{w}$ wymiarach fizjologicznych (przyspieszenie rytmu serca i oddechów, zwiększone wydzielanie hormonów, pocenie się, utrata wagi), psychologicznym (depresja z apatią lub agresywnością, stereotypie), behawioralnym (wycofanie, wokalizy, postawy), choć oczywiście gatunki objawiają je również na własny sposób (rozszerzone nozdrza i źrenice u konia albo chowanie głowy u psa) ${ }^{21}$.

Studia nad zwierzętami przybrały ostatnimi laty ekspansywny charakter, dzięki czemu w polu naukowych badań znalazły się pomijane dotąd punkty widzenia, historie, relacje i wyparte doświad-

${ }^{20}$ Ibidem, s. 55.

${ }^{21}$ É. Baratay: Zwierzęcy punkt widzenia..., s. 147. 
czenia zwierząt. Można uznać, że forma jakiejkolwiek ich deprecjacji lub kwestionowania ich suwerenności, złożoności emocjonalnej, podmiotowości i podatności na ból ${ }^{22}$ świadczy o regresie intelektualnym oraz ignorancji dotychczasowych odkryć z zakresu etologii, psychologii zwierząt i działań ruchu prozwierzęcego, który, jak podkreśla Gzyra, „mozolnie zmaga się nie tylko z potężnym, wieloaspektowym mechanizmem celowej eksploatacji zwierząt" ${ }^{\prime 23}$, lecz również z mechanizmami psychologicznymi, czyniącymi „z ludzi niepodatnych na zmianę przychylną zwierzętom, a z eksploatacji rzadko kwestionowaną normę społeczną" ${ }^{24}$.

Doniosłość animal studies wynika $\mathrm{z}$ ich interwencyjnego potencjału i faktu skupienia uwagi na żywym, autonomicznym stworzeniu, którego los nierzadko krzyżuje się z ludzkim losem. Częściej pozostaje on jednak poza świadomością człowieka, co prowadzi do serii nadużyć, przemocy i prób podporządkowania zwierząt grupie interesu, mającej wymierne korzyści z przemysłowych ferm futrzarskich, ubojni, mleczarni. Zwolennicy nowego porządku, który obligowałby do postrzegania zwierząt jako pełnoprawnych członków wspólnoty, postulują otoczenie opieką każdego przedstawiciela wszystkich gatunków, mimo że „parasol ochronny, przywilej imion, biografii, pieszczot, opieki aż do naturalnej śmierci zarezerwowany jest normalnie jedynie dla zwierzęcych wybrańców" ${ }^{\prime 25}$. Postulat Gzyry demaskuje ludzką krótkowzroczność i niewdzięczność. Emocjonalna relacja może, zdaniem aktywisty, zawiązać się między człowiekiem a wybrańcami, wśród których prym wiodą domowi pupile, obdarzeni imieniem, indywidualną metryką i specjalnym jadłospisem. Wśród uprzywilejowanych znajdują się również zwierzęta zasłużone i słynni towarzysze władców ${ }^{26}$. Całej rzeszy zwierząt nie przysługują wspomniane przywileje, natomiast zakres obowiązków, jakimi je obarczono, często przekraczał możliwości pojedyn-

22 Dariusz Gzyra, komentując książkę Victorii Braithwaite Do Fish Feel Pain?, pisze: „To właśnie Braithwaite była współautorką - szeroko później komentowanych i kontynuowanych przez innych - badań zdolności ryb do odczuwania, które udowodniły, że na skórze pstrągów tęczowych znajdują się nocyceptory (receptory bólu) o właściwościach zbliżonych do występujących u ptaków i ssaków". (IDEm: Dziękuję za świńskie oczy..., s. 238). Zob. również J. Котт: Powiastki dla wnuczek. Warszawa 2002.

${ }^{23}$ D. Gzyra: Dziękuję za świńskie oczy..., s. 317.

${ }^{24}$ Ibidem.

${ }^{25}$ Ibidem, s. 345.

${ }^{26}$ E. Domańsкa: Nekros. Wprowadzenie do ontologii martwego ciała. Warszawa 2017, s. 294. 
czych reprezentantów gatunku. Co prawda, Éric Baratay stwierdza: „Historia tworzy również chwile i sytuacje, kiedy zwierzę postrzega się i traktuje jak czującą istotę mniej lub bardziej szanowaną, a nawet jak jednostkę, »osobę«, z którą nawiązuje się ważną relację, czasem na zasadzie równego z równym”27, jednak trudno rozpatrywać dostrzeżone relacje w kategoriach reguły. Częściej zwierzęta spotykają się z człowiekiem akcydentalnie, a przypadkowość tych spotkań dyktuje niehumanitarne sposoby ich traktowania (co również skrupulatnie odnotowali Baratay ${ }^{28}$ i Gzyra ${ }^{29}$ ).

Najgorszym przewinieniem ludzi względem zwierząt jest przemoc i właśnie ten aspekt podkreślają badaczki i badacze reprezentujący animal studies. Nie zawsze jest ona manifestowana w sposób, który pozwala na natychmiastowe reakcje, częściej przybiera zawoalowane formy: zwierzęta domowe są zaniedbywane, przekarmiane, pozbawiane ruchu, hodowane i rozmnażane w pseudohodowlach dla zysku, upokarzane, w końcu - porzucane czasowo lub ostatecznie:

Zwierzęta są nagminnie i dotkliwie karane za zachowania, za które w dużej mierze odpowiadają ludzie. Ludzcy ignoranci, którzy rzadko zasługują na miano opiekuna lub opiekunki. Trzeba dodać, że udomowienie, rozumiane jako akceptacja przez człowieka bliskich relacji ze zwierzęciem i jego obecności w ludzkim domu, bardzo często bywa warunkowe. Jeśli nie spełniasz oczekiwań, za bardzo utrudniasz ludzkie życie, przestajesz być zwierzęciem towarzyszącym. Wylatujesz z domu i kończysz na ulicy lub w schronisku. Nie nadajesz się, by być częścią wspólnoty. Więcej z tobą kłopotu niż pożytku z ciebie. Niczemu nie jesteś winny, ale skazują cię na najgorsze. Nie przestajesz być udomowiony, ale stajesz się bezdomny ${ }^{30}$.

Więcej form przemocy wobec zwierząt omawia Gzyra w eseju zatytułowanym Zapomniany wymiar przemocy domowej31, podkreślając, że domestykacja zwierzęcia zawsze pociąga za sobą przemoc, bez względu na to, czy jest ono wykorzystywane ponad siły, czy kochane i rozpieszczane. Często bowiem żyje ono według narzuconych reguł i musi zachowywać się zgodnie ze ścisłymi wytycznymi.

Przemoc wobec zwierząt ujawnia się nie tylko pod postacią dobrze znanych i opisanych procedur pozyskiwania krowiego mleka,

${ }^{27}$ É. Baratay: Zwierzęcy punkt widzenia..., s. 211.

${ }^{28}$ Ibidem.

${ }^{29}$ D. Gzyra: Dziękuję za świńskie oczy..., s. 137-180.

${ }^{30}$ Ibidem, s. 39.

${ }^{31}$ Ibidem, s. 33-42. 
mięsa, futra z lisów, norek, lecz przyjmuje także wymiar pojedynczych aktów podtapiania, podduszania, maltretowania, okaleczania i zabijania psów, kotów, a także koni, krów i świń ${ }^{32}$. Za znęcanie się ze szczególnym okrucieństwem nad słabszymi i nieuprzywilejowanymi zwierzętami grozi odpowiedzialność karna (do pięciu lat pozbawienia wolności), jednak sprawcy morderstw i przemocy często pozostają bezkarni. W Polsce wciąż nie wypracowano systemu nadzorowania zwierząt powierzanych opiekunom, a zabójstwo zwierzęcia nie jest na tyle medialne, by sprowokować zmiany legislacyjne. Zwierzęta doznają krzywd za zamkniętymi drzwiami i za przyzwoleniem sąsiadów. Można je torturować na wiele sposobów, a wiele z tych czynów nie zostanie uznanych za przemoc.

W ostatnich latach wydano kilka kluczowych rozpraw ${ }^{33}$ sytuujących się $\mathrm{w}$ obszarze animal studies, których zadaniem było zrewolucjonizowanie myślenia o zwierzętach i dekonstrukcja pokutujących przesądów na temat ich ograniczonych horyzontów poznawczych czy egzekwowanej siłą konieczności uczestnictwa w wojnach, powstaniach, rewolucjach. Prace te rejestrują zmianę poglądów człowieka na kwestię związaną z zajmowanym przez niego miejscem $\mathrm{w}$ hierarchii gatunków ${ }^{34}$. Każdą kolejną publikację na ten temat należy powitać z nieskrywanym entuzjazmem. Szczególnie, jeśli pomyślana jest ona

32 W Polsce istnieje azyl dla świń - „Chrumkowo”, zlokalizowany w pobliżu Torunia, którego misją jest ratowanie świń i zapewnienie im godnej opieki. Zob. wywiad z założycielkami azylu: Z miłości do świń. https://krytykapoli tyczna.pl/kraj/z-milosci-do-swin/ [dostęp: 26.07.2020].

33 Zob. R. Braidotti: Po człowieku. Przeł. J. Bednarek, A. Kowalczyk. Warszawa 2014; K. KRupiński: Dlaczego gęsi krzyczały? Zwierzęta i Zagłada w literaturze polskiej XX i XXI wieku. Warszawa 2016; A. Filipowicz: (Prze)zwierzęcenia...; Poetyki ekocydu. Historia - natura - konflikt. Red. A. Ubertowska, D. Korczyńska-Partyka, E. Kuliś. Warszawa 2019; A. Ubertowska: Historie biotyczne. Pomiędzy estetyka, a geotrauma. Warszawa 2020.

34 Éric Baratay pisze: „Musimy przestać patrzeć i myśleć z perspektywy pępka świata, za jaki się uważamy, zacząć prowadzić badania z szerokim gestem, aby lepiej widzieć i podkreślać zdolności oraz predyspozycje zwierząt $\mathrm{w}$ ich gatunkowym zróżnicowaniu, do tej pory bowiem tylko je negowaliśmy lub ukrywaliśmy, broniąc pozycji i przywilejów, które przyznaliśmy sobie jako gatunek ludzki. Jeśli zapomnimy na chwilę o myśleniu kastowym, na którym od starożytności do dziś opiera się większość religijnych, filozoficznych, naukowych tez, próbujących definiować zwierzęta, zdziwimy się - pozostając wyłącznie na poziomie intelektualnym - jak bardzo są one ubogie, zaślepione, upraszczające wobec żywych istot, które okazują się tymczasem bytami wyjątkowymi w skali wszechświata, ponieważ do tej pory nie odnaleźliśmy żadnych innych". (IDEm: Zwierzęcy punkt widzenia..., s. 330). 
jako pięciusetstronicowe kompendium z zakresu funkcjonowania imaginarium zwierzęcego $\mathrm{w}$ poezji polskiej.

Takim przewodnikiem, który pozwala zorientować się zarówno laikom, jak i badaczom z obszaru animal studies w kwestiach dotąd pomijanych lub tylko sygnalizowanych, jest książka Anity Jarzyny ${ }^{35}$ : Post-koiné. Studia o nieantropocentrycznych językach (poetyckich) ${ }^{36}$. Propozycję prześledzenia sposobów funkcjonowania obrazów zwierząt $\mathrm{w}$ poezji polskiej pod względem doboru egzemplifikacji trzeba uznać za jedno z najlepiej przygotowanych i zrealizowanych przedsięwzięć. Badaczka, pisząc o zwierzętach, unika sentymentalnych tonów, zbija argumenty o emocjonalnym podejściu do tematu, dba o wyważenie własnych racji i wiedzy etologicznej. Jej wywód jest precyzyjny, ponieważ dobrze wie, jak łatwo kwestionować treść publikacji, z których przebija żarliwość, zmieniająca się w histerię.

Jarzyna dba także o to, by nikt nie postponował poezji jako języka zdolnego przekazać nieopisywalne i nienazywalne. W jej monografii priorytetem jest zwierzę i wiersz jako reakcja na niezawinione cierpienie oraz obrona przeciw ignorancji i wykluczeniu. To aż nadto, by uznać ten projekt za wartościowy nie tylko ze względu na temat, lecz również samoświadomość i metakrytyczny potencjał refleksji autorki. Ważenie słów ma ogromne znaczenie w przypadku zwierząt, których losem obserwatorzy potrafią się wzruszać akcydentalnie (caus Letnich Igrzysk Olimpijskich w Pekinie, przed którymi ze stolicy Chin wywieziono kilkaset tysięcy kotów, by je zabić lub uwięzić na peryferiach miasta) $)^{37}$.

Na uwagę zasługuje formuła tytułowa, która w sposób szczególny dowartościowuje poezję, a więc mowę na tyle idiomatyczną i wystrzegającą się językowej sztancy, że może ona gruntownie rozmontować antropocentryczną perspektywę i zbliżyć się do jednostkowego doświadczenia zwierząt. Jak podkreśla Jarzyna, posthumanistyka potrzebuje otwartej, międzygatunkowej, niestabilnej formuły utożsamienia z językiem, który

${ }^{35}$ Na dorobek naukowy Anity JARZYNY składają się, poza omawianą rozprawą, trzy publikacje: Pójście za Norwidem (w polskiej poezji współczesnej). Lublin 2013; Spowiedź wyobraźni (szkice i rozmowy). Wybór, wstęp A. Jarzyna. Kraków 2014; Imaginauci. Pismo wyobraźni w poezji Bolesława Leśmiana, Józefa Czechowicza, Krzysztofa Kamila Baczyńskiego, Tadeusza Nowaka. Łódź-Kraków 2017.

${ }^{36}$ A. Jarzyna: Post-koiné. Studia o nieantropocentrycznych językach (poetyckich). Łódź 2019. Dalsze przywołania z tej książki oznaczam numererem strony, bezpośrednio po cytatach.

37 D. Gzyra: Dziękuję za świńskie oczy..., s. 229. 
przychodzi „po” koiné, przygląda się z boku, nierzadko krytycznie, wypracowanemu konsensusowi, zastanemu słownikowi wspólnoty (również słownikowi humanistycznych dyscyplin), tak łatwo i często manipulującemu zwierzęcą leksyką. Post-koiné stara się dosięgnąć bezmownej (i często nienazwanej) reszty, niekoniecznie nawiązać przy tym trwałą więź czy porozumienie, przede wszystkim nie wyróżniać ludzkiej pozycji, ludzkiego podmiotu spośród innych gatunków. O ten język upomina się poezja - w swej istocie polifoniczna - która od razu zrzeka się dyktatorskich roszczeń, zawsze obejmuje wiele idiomów, wiele wyobraźni niedających się ujednolicić, sprowadzić do jednej perspektywy. Jako taka zdaje się post-koiné ustanawiać inkluzywną formułę wspólnoty

W książce Jarzyny można dostrzec trzy komplementarne narracje. Pierwsza dotyczy pojedynczych epizodów z biografii psów (zarówno znanych powszechnie, jak Łajka, a także unieśmiertelnionych w poezji, jak Binio Piotra Sommera), druga - obejmuje zjawiska zachodzące w języku (eufemizowanie procederu mordowania zwierząt przez myśliwych oraz przechwytywania i neutralizowania, a nawet dowartościowywania animalnych inwektyw, których podstawą są wyobrażenia o niepohamowanym rozrodzie zwierząt, a także leksyka myśliwska unieważniająca podmiotowość istot określanych tymi słowami), trzecia natomiast koncentruje się na strategiach konstytuujących nowy sposób uprawiania przyrodopisarstwa oraz wykluczania zwierząt ze wspólnoty istot podatnych na zranienie przez Katechizm Kościoła katolickiego.

Projekt Jarzyny wiele zawdzięcza postulatom Érica Barataya, który twierdzi, że „żywe zwierzę nie może nadal być białą plamą historii" ${ }^{\prime 38}$. Na dowartościowanie - zdaniem francuskiego historyka zasługują nie tylko pojedyncze biografie zwierząt, lecz również to, co dzieje się w momencie interakcji (nie tylko języka i animalnego imaginarium). Zaproponowane przez Jarzynę dualne podejście wiele zawdzięcza pracom Barataya. W Zwierzęcym punkcie widzenia... pisze on o postawach względem zwierząt jako paradygmatycznym modelu zachowań, jednak wiele przesądów i uprzedzeń przenika do ludzkiego języka, zasilając go i uzbrajając w obelżywe inwektywy:

Zwierzęta żyją w warunkach narzuconych przez ludzi, poczynając od brutalnego przymusu aż do przyjacielskiej namowy, ale reagują na nie (różnie i zmiennie $\mathrm{w}$ zależności od jednostek albo sytuacji), a ich postawy odbijają się na postawach ludzkich, mo-

38 É. Baratay: Zwierzęcy punkt widzenia..., s. 21. 
dyfikując je w nieustannej grze interakcji. Ukazanie doświadczanych warunków oraz odgrywanych ról pozwala dotrzeć do bardziej złożonego obrazu rzeczywistości; gdy zaś przyzwalamy na rozszerzenie historii i decentralizację spojrzenia, rzeczywistość tę w końcu łatwo odnaleźć, obserwować, opisać. Zwierzęca strona uzupełnia i wzbogaca stronę ludzką, ma też jednak swoją autonomię i własną wartość, docenianą ze względu na coraz większe zainteresowanie zwierzętami oraz rosnące obawy co do przyszłych losów bioróżnorodności. Z przejścia na stronę zwierząt, prowadzenia opisu z ich „punktu widzenia” - przy szerokim rozumieniu tego wyrażenia o dwojakim sensie: pozycji geograficznej, z której można patrzeć na zwierzę i na świat, oraz treści psychologicznej czekającej na odtworzenie - płynie zatem podwójny pożytek ${ }^{39}$.

W Post-koiné... szczególny nacisk położony został na dowartościowanie pojedynczych wierszy (m.in. Płaczu Jerzego Kronholda), co skutkuje stworzeniem przez Jarzynę budzącej podziw konstelacji tekstów, które ze sobą interferują i wzajemnie dialogują, a także nakreślają unikalną w polskich studiach nad zwierzętami siatkę problemów. Każdy z rozdziałów książki prezentuje sztukę interpretacji, którą charakteryzuje optyka szczegółu.

Śledząc kolejne wątki i rozbudowane partie monografii, można dostrzec zastosowanie kategorii pozornie nieprzylegającej do opisu zabójstwa zwierzęcia z obszaru studiów nad ludobójstwami. Badaczka celowo wprawia czytelnika w konsternację i sprawia, że jego dotychczasowy sposób postrzegania znanych (być może z autopsji lub z mediów) faktów ulega zmianie. Autorka, pisząc o wierszu Justyny Bargielskiej ***[ruda się okociła jak tata był w delegacji...] z tomu Dating sessions, powołuje się na jedno z ogniw Hilbergowskiej triady ${ }^{40}$ : status „nie-sprawcy” (a dokładnie na opisaną przez autora Zagłady europejskich Żydów pozycję ofiary). Wzmianka pojawia się w nawiasie, co może sugerować osłabienie efektu promieniowania teorii historyka na zjawiska niezwiązane z Zagładą. Usytuowanie nazwiska Hilberga w kontekście okoliczności zabójstwa kociąt może zostać uznane przez czytelnika za zbyt jednoznaczne sąsiadowanie wydarzenia o skali nieporównywalnej do opisanego mordu. Planowe wytrącenie czytelnika z rutynowego sposobu myślenia o zwierzęcych ofiarach wiąże się z demontażem języków opisu cierpienia ludzi i nie-ludzi. Włączenie zwierząt do Hilbergowskiej

${ }^{39}$ Ibidem, s. 33.

${ }^{40}$ R. Hilberg: Sprawcy - ofiary - świadkowie. Zagłada Żydów 1933-1945. Przeł. J. GiebuŁtowski. Warszawa 2007. 
triady (taki postulat wysunęła $\mathrm{w}$ jednym $\mathrm{z}$ artykułów Aleksandra Ubertowska ${ }^{41}$ unieważnia hierarchizację cierpienia ze względu na rodzaj poniesionych ran, dzięki czemu nawet zwierzęta mordowane w domach (za zgodą domowników i sąsiadów) zyskują status ofiar (brutalnych mordów), których śmierć powinno wyjaśnić dochodzenie. Dyskusyjność zastosowania wspomnianego terminu wiąże się z procesem kategoryzowania ofiar (Hilberg w swojej książce wyszczególnił kilka grup ofiar ze względu na kryterium genderowe, majątkowe, społeczne). Wiele ofiar pragnęło za wszelką cenę przekroczyć bariery, które miały zadecydować o ich śmierci, natomiast kocięta z wiersza Bargielskiej nie mają szans na przeżycie, ich śmierci nie poprzedzają żadne działania na rzecz ocalenia życia. Pod tym względem paraliżuje ona nie tylko „zagłaskanego" obserwatora, lecz również czytelnika. Ofiarą, według Jarzyny, jest każda istota, nad którą zaocznie ciąży wyrok śmierci, bez prawa do obrony. W języku polskim być może nie objawia się $\mathrm{w}$ pełni koncept Jarzyny, ponieważ słowo „ofiara” odnosi się zarówno do przypadków ludobójstwa, pojedynczego morderstwa i przemocy domowej, jednak $w$ języku angielskim słowa "prey" i „victim" zarezerwowane są odpowiednio: dla zwierząt jako ofiar łowów urządzanych przez inne zwierzęta oraz ludzi.

Jarzyna, przywołując kategorie Hilberga, celowo naruszyła granicę między tym, co dotyczy ludzi i zwierząt, jednak warto zapytać o status referującej historię „dropiatych skórek”. Czy byłaby ona świadkiem?

Susan Sontag twierdzi, że „Praktyka przedstawiania okrutnych cierpień jako czegoś, nad czym należy ubolewać i czemu trzeba w miarę możliwości położyć kres, wkracza do historii obrazów ze specyficznym tematem: cierpieniami zadawanymi ludności cywilnej przez zwycięską armię $\mathrm{w}$ bitewnym szale"42, a więc podążając za myślą autorki Widoku cudzego cierpienia, nazwisko Hilberga mogłoby się pojawić, gdyby $\mathrm{w}$ polu obserwacji Bargielskiej znalazły się masowe zbrodnie popełniane na zwierzętach $\mathrm{w}$ warunkach wojennych. Koncepcja bycia świadkiem w Holocaust and Genocide Studies obwarowana jest siatką zbyt wielu obostrzeń, by mogła sprawdzić się w przypadku zabójstwa kociąt. We wciąż ewoluujących studiach nad Zagładą przyjmuje się aktywną rolę świadka jako decydenta,

${ }^{41}$ A. Ubertowska: Natura u kresu (ekocyd). Podmiotowość po katastrofie. „Teksty Drugie” 2013, nr 1-2, s. 33-44. Zob. również: EADEM: "Kamienie niepokoją się i staja się agresywne”. Holokaust w świetle ekokrytyki. „Poznańskie Studia Polonistyczne. Seria Literacka" 2015, nr 25, s. 93-111.

42 S. Sontag: Widok cudzego cierpienia. Przeł. S. Magala. Warszawa 2010, s. 54. 
którego czyny mogą nie tyle odwrócić bieg wypadków, ile przysporzyć cierpienia ofierze lub za sprawą empatii przywrócić jej godność i podmiotowość. Świadek nie tylko zdaje relację, lecz jest poddawany próbie i promieniowaniu przemocy. Jak twierdzi Giorgio Agamben, to ten, kto „coś przeżył, przetrwał coś do samego końca, a zatem może dać temu świadectwo. W sposób oczywisty Levi nie jest osobą trzecią, w każdym możliwym sensie jest on super-stes, tym, który prze-trwał, tym, który prze-żył - ocalałym" ${ }^{\prime \prime 3}$. Nie twierdzę, że zwierzę ocalałe z wojennej pożogi nie jest świadkiem (co potwierdzają publikacje Barataya), jednak status mówiącej o śmierci kociąt zbliża się do kategorii terstis - „kogoś, kto w postępowaniu sądowym bądź $w$ sporze między dwiema stronami występuje w charakterze osoby trzeciej" ${ }^{\prime 4}$. W wierszu Bargielskiej dominuje perspektywa (pasywnego) świadka. Bez wątpienia do sytuacji opisanej przez poetkę przystaje bycie świadkiem przemocy domowej, dokonywanej za zamkniętymi drzwiami i przy milczącej zgodzie domowników. Ten aspekt biografii zwierząt domowych pozostaje pominięty, ponieważ wśród zajmujących się nimi panuje ciche przyzwolenie na ich krzywdę (pozostawianie samych na długie godziny, okładanie pięściami, używanie obroży zamiast szelek, mordowanie nowego miotu) i unikanie odpowiedzialności, a także bagatelizowanie zachowań przemocowych. Częstokroć rodziny, w których dochodzi do przemocy wobec zwierząt, opiekują się także małymi dziećmi - świadkami nadużyć. Wyszczególnienie zarysowanego tu problemu (o ile pozwoliłaby na to liczba wierszy i relacji) mogłoby stać się przyczynkiem do powstania szkicu o "cichej przemocy", znamionującej ludzką hipokryzję, manifestowaną także w wierszu Bargielskiej:

ruda się okociła jak tata był $\mathrm{w}$ delegacji

lizała dropiate skórki $\mathrm{w}$ zdziwieniu ile słońc może wybuchnąć wypłynąć z kotki zrobiło się późno z jej winy skórki otwierały oczy na świat język rudej opowiadał o nim mleczny tykający w rytm niespiesznych napięć i odprężeń wyczekany z zachwytu życiem uschły a potem odpadły skórkom powieki tata wrócił ciężko było zamknąć raz otwarte niefrasobliwie zmierzam do tego że wylizujesz ze mnie resztki ciemności jak tata

${ }^{43}$ G. Agamben: Co zostaje z Auschwitz. Archiwum i świadek. Przeł. S. Królak. Warszawa 2008, s. 15.

${ }^{44}$ Ibidem. 
wyszedł z workiem mama zagłaskała we mnie pamięć jak się zabija ale pamiętam jak się ginie przecie $\dot{z}^{45}$

"Zagłaskiwanie" pamięci o fakcie zabijania zwierząt to domena dorosłych, którzy uważają, że wyjaśnienie dzieciom powodu bycia świadkami morderstwa lub konieczności antycypowania jego zaistnienia, jest zbędne. Poetka bazuje $\mathrm{w}$ wierszu na paralelizmach: kocica lizała dropiate skórki, natomiast ty, określane przez Jarzynę jako ","ty" kojące, wtajemniczone w przedlogocentryczny język kocicy" (s. 348), wylizuje resztki ciemności, a więc odsłania to, co wymyka się rozumowi - dziecko przygląda się procederowi uprzątania ciał dzieci, utrata miotu sąsiaduje z utratą własnego dziecka. Przywołany wiersz jest oskarżeniem i gorzkim wtajemniczeniem $\mathrm{w}$ arkana życia bez znieczulenia. Drastycznym, ponieważ wysłowionym w mowie dziecka i bazującym na zestawieniu radości z powitania nowego życia i smutku z powodu konieczności jego pożegnania. Zdaniem Jarzyny: „Bargielskiej udaje się przez chwilę, przez tych kilka pierwszych linijek, wyciszyć ludzki głos, znaleźć się możliwie najbliżej perspektywy doświadczenia tej konkretnej matki - jej radości, instynktu oraz intuicji, jak zapewnić swym dzieciom poczucie bezpieczeństwa i ciepła" (s. 347).

To nie jedyny wiersz, w którym dziecięca idylla fałszywie współistnieje $\mathrm{z}$ morderstwem. W Amateurpissing paralelizmy (pasztet z królika i dziecięcy bryzol) uświadamiają brak różnicy (poza istniejącym w kulturze tabu wobec spożywania mięsa ludzkiego) między jednym a drugim rodzajem pożywienia. Ostatecznie zwierzę zawsze znajduje się na przegranej pozycji (a właściwie wygrywa w pojedynku na drastyczność ze względu na sposób zadania zwierzęciu śmierci i przedśmiertną relację z dziećmi):

Nie wiedzą, że wystarczy przenieść się ze stypą do restauracji, by stała się konsolacją, tylko jedzą co rano te swoje bułki z pasztetem z królika, z którym jeszcze wieczorem bawiły się dzieci, dwukątne stworzenia mające najwięcej wspólnego z mydłem i bryzolem. A gdy im rozdzwoniony tramwaj przejedzie po nogach, nie mają w odpowiedzi historii tak krwawej, by nią mogli bez wstydu podjąć jego wyzwanie $[\ldots]^{46}$

45 J. BARGIELSKA: ${ }^{* *}[$ ruda się okociła jak tata był $w$ delegacji...]. W: EADEM: Szybko przez wszystko. Wrocław 2013, s. 36.

46 J. Bargielska: Amateurpissing. W: Eadem: Szybko..., s. 89. 
Bargielska obrazowo (za sprawą montażu, przywołującego dokonania surrealistów) ${ }^{47}$ podważa nie tylko zasadność roszczeniowej postawy ludzi wobec nadawania ich przygodom ciała (nawet tak krwawym jak okoliczności wypadku komunikacyjnego) szczególnej rangi, lecz również opowiada historię zwierzęcej śmierci w sposób zarezerwowany dla męczenników, akcentujący ich martyrologię.

Niekwestionowanym atutem publikacji Jarzyny jest odrzucenie twierdzenia, że należy zajmować się tylko tymi tekstami poetyckimi, których autorzy bezpośrednio stawiają sobie za cel reprezentację zwierząt lub ich dyskursywną obronę. Nawet wiersze pozbawione interwencyjnego charakteru i skupiajacce się na pogłębieniu antropocentrycznej perspektywy przykuwają uwagę właśnie ze względu na wyparcie, przemilczenie, wypaczenie lub zniekształcenie obrazu zwierząt. Badaczkę interesują więc nie tylko satysfakcjonujące próby zbliżenia się do zwierząt przez medium poezji, lecz również projekty chybione, w jakimś stopniu wadliwe i bazujące na stereotypach. Tylko w ten sposób możliwe jest obnażenie mechanizmów językowych, uproszczeń, zawłaszczeń i ugruntowanych sądów na temat zwierząt. Można postawić tezę, że proponuje ona w swojej monografii znacznie więcej niż obiecuje we wstępie, ponieważ kolejne rozdziały uświadamiają czytelnikowi, w jakim stopniu zwierzęta stały się wrogami człowieka, choć wymierzona przeciw nim kampania oszczerstw i nienawiści nie ma żadnych podstaw.

Poza tym Jarzyna niebezzasadnie twierdzi, że nawet teksty odbiegające od konwencji realistycznej i skłaniające się ku baśniowości świadczą o pewnym sposobie postrzegania zwierząt w poezji współczesnej, który można uznać za dopuszczalny lub niestosowny, infantylny bądź szkodliwy:

Poezja bowiem (szerzej: pewna wrażliwość, pewien typ poetyckich działań na języku, nie zawsze przecież objawiających się w wierszu) zaświadcza, że niekoniecznie konwencja realistyczna jest jedynym sposobem nieantropocentrycznego przedstawiania zwierząt. Poezja potrafi zaczarować je ponownie, tym razem już nie po to, by uczynić z nich symbole odsyłające do ludzkiego świata, lecz by ukazywać w ten sposób ich osobność, na nowo zdefiniować ich miejsce w od teraz międzygatunkowym świecie oraz co jeszcze trudniejsze do pogodzenia $\mathrm{z}$ zastanym imaginarium - w międzygatunkowej duchowości.

s. 41

${ }^{47}$ Niektóre wiersze Bargielskiej przywodzą na myśl surrealistyczne pocztówki, często oparte na kolażu. Zob. A. TавоRsкA: Spiskowcy wyobraźni. Gdańsk 2013, s. 14-36. 
Jeśli pokusić się o wytyczenie pola działań przedstawicieli studiów nad zwierzętami, to bez wątpienia najczęściej domeną eksploracji badawczych okazują się: proza, dokument osobisty i epistolografia. Wynika to m.in. z predyspozycji prozy do osadzania relacji ze zwierzętami w kontekście autobiografii pisarzy i referencjalności, która pozwala przypuszczać, że wszyscy nie-ludzcy aktorzy zostali sportretowani z pamięci, a ich istnienie nie podlega dyskusji. Proza bazuje też na konkretniejszych opisach, które nie pozostawiają wątpliwości co do wyglądu i zachowania zwierzęcia. Jego namacalną dotkliwość fundują szczegóły, perspektywa świadka, reporterska obiektywność lub zdolność do kreowania doświadczeń zarezerwowanych dla zwierzą ${ }^{48}$. Niekwestionowanym atutem tekstów prozatorskich jest również odpowiednia fokalizacja.

Natomiast gościnność poezji polskiej względem zwierząt objawia się za sprawą tropów, które Donna Haraway uznaje za najważniejsze strategie językowe:

Trop (z gr. tropós) oznacza odchylenie lub skręt. Język jako taki nie robi nic innego, jak tylko odchyla się od właściwego kursu i skręca; nie ma znaczenia bezpośredniego; tylko dogmatycy myślą, że możemy żyć w świecie komunikacji pozbawionej tropów. Moim ulubionym tropem prowadzącym do opowieści o psach jest metaplazm. Oznacza on przekształcenie słowa, na przykład poprzez dodanie, usunięcie, przestawienie lub zamianę liter, sylab lub głosek. Termin pochodzi od greckiego słowa metaplasmos, oznaczającego powtórne kształtowanie lub formowanie. Metaplazm to termin ogólny dla niemal każdego przekształcenia w obrębie słowa, zamierzonego lub niezamierzonego ${ }^{49}$.

Nie mniej istotne okazują się paradoksy, przerzutnie, wyrażenia idiomatyczne, paronomazja, a więc koncepty znane z poezji lingwistycznej Joanny Mueller. Oczywiście, zasada językowej ekwilibrystyki nie jest jedynym kryterium wyboru wierszy, które zostały przez Jarzynę omówione, jednak wskazuje na możliwości poezji i jej wiążący charakter (nie tylko na poziomie tropów i bohaterów, lecz także nawiązań, inspiracji i powtarzania natrętnie powracającej frazy).

48 A. Kramkowska-Dąbrowska: Krasiński. Świadectwo. Łódź 2020, s. 115-117; A. Galant: Polowania i linienia. Śmierć zwierzat w wybranej prozie kobiet. W: Twórczość niepozorna. Szkice o literaturze. Red. J. GrąDziel-Wójcik, A. Kwiatкowsкa, L. Marzec. Kraków 2015.

49 D. Haraway: Manifest gatunków stowarzyszonych. Przeł. J. Bednarek. W: Teorie wywrotowe. Antologia przekładów. Red. A. Gajewska. Poznań 2012, s. 255. 
Należy dodać, że badaczka postawiła przed sobą ambitne zadanie, polegające na prześledzeniu wyobraźni animalnej, objawiającej się $\mathrm{w}$ tekstach poetów, należących do różnych formacji pokoleniowych i hołdujących odmiennym regułom organizacji wiersza (casus Ryszarda Krynickiego skłaniającego się ku formom gnomicznym i Stanisława Grochowiaka sondującego możliwości reprezentacji zwierząt za sprawą poematu ${ }^{50}$ ).

Zastrzega ona jednak, że nie interesują jej dokonania poetek i poetów jednoznacznie zgłaszających swój akces do wspólnoty twórców propagujących postantropocentryczną świadomość, wrażliwych na nowe relacje oraz powiązania ludzi i nie-ludzi (m.in. Anny Adamowicz, Małgorzaty Lebdy, Ilony Witkowskiej, Kiry Pietrek, Julii Fiedorczuk, Kacpra Bartczaka, Michała Czai, Edwarda Pasewicza). Większość autorek i autorów przywoływanych przez Jarzynę należy do kanonu poezji polskiej, dlatego akcentowanie perspektywy zoocentrycznej w wierszach twórców lokowanych dotąd w obszarze innych problemów i zagadnień jest posunięciem tyleż intrygującym, co niebezpiecznym. Jarzyna zdaje sobie bowiem sprawę z faktu, że wielu poetów nie mogłoby pojawić się $\mathrm{w}$ jej monografii na prawach paradygmatycznych przykładów wyobraźni animalnej, jednak do spełnienia postawionych przez nią kryteriów przenicowywania dyskursu antropocentrycznego wystarczy jeden wiersz, często na tyle idiomatyczny, że zapewniający danemu poecie akces do zrzeszenia twórców objawiających wrażliwość posthumanistyczną.

Nie wszyscy oczywiście wykorzystują tę szansę w sposób zadowalający ${ }^{51}$. Do grona twórców, których dorobek podlega mi-

${ }^{50}$ O Elegii oborskiej Stanisława Grochowiaka pisała również Beata Мүтүсн-Forajter: Czułe punkty Grochowiaka. Szkice i interpretacje. Katowice 2010, s. 119135, natomiast o Polowaniu na cietrzewie pisał Jacek Łukasıewicz: Poeta Grochowiak. Wrocław 2019, s. 163-172.

${ }^{51}$ Oto komentarz badaczki do dwóch wierszy Jerzego Kronholda (Płacz i Życie ptaków i ssaków po): „Płacz (wraz z wierszem Życie ptaków i ssaków po, którym się już zajmowałam) sytuuje się, jak sygnalizowałam, na samych skrajach twórczości Kronholda, nie jest dla niej symptomatyczny, nie zapowiada też radykalnej zmiany w figurach wyobraźni czy rewizji języka. Kiedy poeta mówi o cierpieniu zwierząt, raczej nie przyjmuje ich pozaludzkiej perspektywy. W innych jego wierszach śmierć kociąt wrzuconych do rzeki czy śmierć wyżła potrąconego przez samochód wzbudzają może minimalne współczucie, w przypadku psa raczej wyrzuty sumienia, ale ostatecznie są asemantyczne, nie skłaniają do refleksji na przykład nad tym, że zwierzęta umierają inaczej niż ludzie (a przecież mowa tu o tak zwanych zwierzętach domowych). Skłaniają za to - w innym porządku - do refleksji nad zredukowanym, sformatowanym językiem" (s. 398-399). 
krologicznemu oglądowi, należą m.in. Justyna Bargielska, Zuzanna Ginczanka, Jerzy Ficowski, Julia Hartwig, Zbigniew Herbert, Feliks Konopka, Jerzy Kronhold, Michał Książek, Krystyna Miłobędzka, Joanna Mueller, Andrzej Niewiadomski, Tadeusz Nowak, Jacek Podsiadło, Nelly Sachs, Piotr Sommer, Dariusz Suska, Tadeusz Śliwiak, Anna Świrszczyńska i Adam Zagajewski. Ułożona przeze mnie lista $\mathrm{w}$ porządku alfabetycznym $\mathrm{w}$ sposób cząstkowy i niepełny poświadcza erudycję Jarzyny i rozmach, który przejawia się na każdym poziomie i w niemal każdym rozdziale monografii. $\mathrm{Z}$ pełnym przekonaniem można stwierdzić, że Jarzyna w Post-koiné... nie grzęźnie $\mathrm{w}$ chłodnym, naukowym dyskursie, jej pasja przejawia się już w geście wyboru epigrafów i świetnie przeprowadzonych wywodach analityczno-interpretacyjnych. Można wskazać z dużym prawdopodobieństwem, które kwestie drażnią badaczkę najbardziej i skłaniają do wyboru tonu znanego z polemik. Atutem książki Post-koiné... jest, jak już wspominałem, jej język. Każde słowo wymaga namysłu, ponieważ może zostać wykorzystane przeciw zwierzęciu.

Monografia Post-koiné... składa się z pięciu części, które w lekturze linearnej dają pełny ogląd polskiej poezji nieantropocentrycznej. Opisywane przez Jarzynę cztery odsłony języka wolnego od roszczeń antropocentryzmu mają także status osobnych kategorii, które powodują demontaż eufemizmów, nazywają i opisują nie-ludzkie doświadczenie zwierząt, stanów wyjątkowych, demaskują utrwalone obyczajem podziały i wykluczenia oraz odpowiadają za aranżowanie nowego świata. Każda aktywność, której badaczka poświęca uwagę, wymierzona jest w trwałe status quo i językowy uzus. Poetyckie działania na języku dążą do zarysowania nowej syntezy mowy, w której mordy, pyski, ryje, dzioby przestaną być składową wyrażeń idiomatycznych (np. kłapać dziobem) i inwektyw.

Sposób postrzegania zwierząt staje się probierzem wrażliwości ekologicznej, a także toruje drogę do nabywania umiejętności zawierania trwałych relacji ze zwierzętami, przy czym należy podkreślić, że badaczka wyszczególnia zarówno obszar doświadczeń granicznych (masakrę stambulskich psów z 1910 roku zestawianą z rzezią Ormian z 1915 roku oraz Zagładę widzianą oczami nie-ludzkich świadków), a także to, co zazwyczaj pozostaje poza obszarem naukowych dociekań (m.in. emocje, takie jak miłość):

Z rozpoznań współczesnych badaczy wynika, że przyjemność zwierzęta (jak ludzie) czerpią z zabawy, przyjaźni, miłości, także piękna. Znamienne, że te emocje, zwłaszcza miłość, należą do najrzadziej omawianych (zdecydowanie częściej bowiem koncentru- 
jemy się na doznaniach negatywnych związanych z bólem i cierpieniem). Wiemy też, że fizjologia rozkoszy u człowieka i innych gatunków bywa podobna, choć często różnimy się ekspresją.

Jarzyna odrzuca wyraźną w studiach nad zwierzętami tendencję do podkreślania ich kondycji jako ofiar i zarysowuje komplementarną narrację, która akcentuje, że „zwierzęta nie tylko odwzajemniają, ale także inicjują kontakt, sygnalizują potrzebę bliskości, są aktywnymi podmiotami, nie służą do pocieszania czy rozśmieszania. $W$ istocie bowiem, dopiero rezygnując $z$ ich stereotypowych przedstawień na przykład jako pupili, można poważnie traktować animalne emocje" (s. 487). Takie podejście okazuje się dynamiczne i sprawiedliwe, ponieważ, mimo tego że zakres krzywd, jakich doznają zwierzęta, pozostaje szeroki, to jednak ich życie (niepowtarzalne w swojej jedyności i oryginalności) nie sprowadza się do wytrzymywania razów i kolejnych upokorzeń, lecz składa się także z chwil, w których dominują silne, pozytywne emocje (radość z bliskości, ulga z powodu przerwania rozłąki, miłość, przyjemność obcowania zwierzęcia z człowiekiem i vice versa). Być może to właśnie w momentach rozkoszy zwierzęta przestają być postrzegane jako pasywne, uległe, poskromione przez człowieka stosującego wobec nich przemoc. Istotne w książce Jarzyny okazują się zatem kontrasty, które nie pozwalają na wychylenie reprezentacji w jedną stronę, co skutkowałoby zafałszowaniem obrazu, uznaniem wszelkich wniosków za tendencyjne i niewspółmierne wobec labilnej prawdy.

Prezentowane przez badaczkę podejście zasługuje na uznanie i podziw, ponieważ spełnia oczekiwania stawiane rozprawom sytuującym się w polu animal studies, dotyczące ujawnienia autonomicznej historii zwierzą ${ }^{52}$, odrzucania uogólniających wniosków, śledzenia perspektywy zwierzęcia z uwzględnieniem wiedzy etologicznej i szacowania strat wizerunkowych, jakie ponoszą zwierzęta, gdy do głosu dochodzą krzywdzące je wizje, zwieńczone zakrawającymi na banał morałami. Jeśli więc praktykowanie tego typu badań ujawnić

52 Éric Baratay pisze: „Czas wyjść poza propagowaną przez większość filozofów koncepcję kulturową, która do niedawna wywierała ogromny wpływ na nauki przyrodnicze i wciąż pokutuje w naukach humanistycznych. Należy przeciwnie - podkreślić znaczenie zwierząt $\mathrm{w}$ relacji z ludźmi, ich rzeczywistą rolę sprawczą, tym bardziej że ich czyny, zachowania, formy towarzyskości, »kultury« (jak mówią współcześni etolodzy) są odgadywane, zauważane, oceniane przez ludzi w terenie - a zatem zwierzęta reagują, działają, myślą". (IDEM: Zwierzecy punkt widzenia..., s. 21). 
ma jakiekolwiek pożytki dla człowieka (choć to postulat, którego brzmienie wydaje się niepokojące), to musi być ono zorientowane zarówno na braki, wyobraźniowe protezy, skróty, jak i naddatki, zmysł formy poetek i poetów, próby zbliżania się do zwierząt za sprawą figur poetyckich, podważających dotychczasowe, sprawdzone sposoby pisania o nich.

Problemy, z jakimi mierzy się Jarzyna, mają doniosłe znaczenie $\mathrm{w}$ procesie forsowania innych, niekanonicznych obrazów zwierzęcej suwerenności. Należą do nich: retoryczne nadużycia związane z porównywaniem Żydów do owiec/baranów prowadzonych na rzeź ${ }^{53}$ (przy czym określenie to funkcjonuje na prawach inwektywy, przysłaniając los zwierząt rzeźnych), podkreślanie analogii między trzecią fazą Zagłady, podczas której Żydzi musieli ukrywać się przed ludnością polską, granatowymi policjantami a polowaniem na dziką zwierzynę ${ }^{54}$, sprowadzanie zwierząt do roli pupilów, pomijające ich złożoność emocjonalną, wykorzystywanie nazw zwierząt jako naznaczających, upokarzających i opresyjnych inwektyw, w końcu językowe maskowanie procederu mordowania zwierząt.

Książkę Jarzyny warto czytać, mając w pamięci opublikowaną w 2017 roku monografię Anny Filipowicz (Prze)zwierzecenia. Poetyckie drogi do postantropocentryzmu. Wiersze, na których bazują obie autorki, z drobnymi wyjątkami są różne, zasadnie jednak uznać te prace za komplementarne, ponieważ tylko wtedy możliwe staje się wieloaspektowe poszerzenie pola refleksji nad statusem zwierząt we współczesnej humanistyce.

O ile jednak Filipowicz udowadnia tezę o szczególnym potencjale języka poetyckiego w zakresie przedstawiania opresyjnych losów zwierząt w XX i XXI wieku na przykładzie twórczości zaledwie kilku autorek i autorów (Anny Świrszczyńskiej, Ryszarda Krynickiego, Jarosława Marka Rymkiewicza, Tadeusza Różewicza, Tomasza Ró-

53 Zob. J. Leociak: "jak owce na rzeź" - figura Zagłady. W: Literatura polska wobec Zagłady (1939-1968). Red. S. Bury£a, D. KrawcZyŃSKa, J. Leociak. Warszawa 2012, s. 159-165.

${ }^{54}$ Jarzyna pisze: „Zatrzymuję się przy tamtych, dłuższych wypowiedziach [wykorzystujących analogię losu Żydów i dzikich zwierząt - A.J.], nie dają mi one spokoju. Ich autorzy zupełnie świadomie próbowali naśladować dzikie zwierzęta, wiedzieli, że $\mathrm{w}$ ten sposób mogą ocalić życie. W istocie doświadczenia, które opisują za pomocą animalnych porównań, przekraczają ramy porównania, wskazują na realną przemianę, upodobnienie. W konsekwencji te relacje - zaryzykowałabym stwierdzenie - dają wgląd w najbardziej podstawowe emocje prześladowanej istoty, niezależnie od jej przynależności gatunkowej pozwalają wyobrazić sobie, jak przeżywa ona polowanie" (s. 185). 
życkiego, Marcina Świetlickiego i Juliana Tuwima), których dobór wynika najpewniej z satysfakcjonujących wyników prób, o tyle Jarzyna dąży do zarysowania nie tylko problemów, ale i niebezpieczeństw, z którymi mierzą się poetki i poeci, opracowując poetycko zwierzęce doświadczenia. Filipowicz zawęziła obszar poszukiwań i starannie wybrała przedstawicieli poezji posthumanistycznej, którzy albo nie byli do tej pory kojarzeni jako rzecznicy nowego ładu, albo pojawiali się akcydentalnie $\mathrm{w}$ opracowaniach poświęconych nowemu paradygmatowi badań. Jej dbałość o dochowywanie wierności konkretnym poetom $\mathrm{w}$ poszczególnych rozdziałach bez wskazywania kontekstów wynika zarówno z chęci panowania nad kompozycją, jak i próby stworzenia autonomicznych rozdziałów-bedekerów dla kolejnych specjalistów.

Jarzyna nie podejmuje w swojej monografii tej strategii. Badaczkę interesują zamierzone koincydencje (Bargielska, Mueller), poświadczane $\mathrm{w}$ mottach i komentarzach krytycznych, bądź autorskie zestawienia (Kronhold, Zagajewski), choć nie unika także spojrzenia mikrologicznego (casus Sachs). Często sięga po teksty dobrze znane, traktując je niczym fragmenty twórczości literackiej (casus Donny Haraway, której opis wymieniania czułości z Cayenne Pepper należy uznać nie tylko za anegdotę wprowadzającą do tekstu naukowego, rozpowszechnionego za sprawą terminu "gatunki stowarzyszone"). Integralną częścią Manifestu gatunków stowarzyszonych są Notatki córki dziennikarza sportowego:

Notatki zakładają, że nie należy odbiegać od samych opowieści o zwierzętach. Przesłanie musi być integralną częścią opowieści; reguła ta obowiązuje wszystkich - praktykujących lub byłych katolików oraz ich towarzyszy podróży - wierzących, że słowo i ciało są jednym. Piszę Notatki, zdając relację z faktów, opowiadając prawdziwe historie ${ }^{55}$.

W polu badań Jarzyny znalazły się nie tylko sojusze, które zawiązują poeci i dzieci w zakresie wyzwalania wyobraźni z pęt antropocentrycznych schematów myślenia o zwierzętach jako poddanych kaprysom człowieka niewolnikach (casus zwierząt laboratoryjnych), lecz również przedsięwzięcia poetyckie, które trywializują relacje ludzko-zwierzęce (casus wierszy Danuty Wawiłow). Zamiarem Jarzyny, konsekwentnie realizowanym $w$ kolejnych rozdziałach, jest określenie poezji jednym z najbardziej gościnnych dyskursów,

${ }^{55}$ D. Haraway: Manifest gatunków stowarzyszonych..., s. 253. 
pozwalającym na empatyczne współodczuwanie z cierpiącymi, poniżanymi i mordowanymi zwierzętami, przy czym solidarność, o jakiej pisze autorka Post-koiné..., daleka jest od hierarchiczności jako jedynej aprobowanej zasady myślenia o współżyciu ludzkich i nie-ludzkich aktorów historii. Poezja jest także rodzajem zobowiązania i paktu opartego na szacunku, trosce i przywiązaniu. Bez względu jednak na to, jak wiele wysiłku włożone zostanie w proces destabilizowania utartych znaczeń przypisywanych "człowieczeństwu” i „zwierzęcości”, fraza „humanitarny ubój” wciąż funkcjonuje jako eufemizm, a nie oksymoron. Jarzyna, tworząc katalog poetyckich strategii podważania różnicy antropologicznej, podkreśla gotowość poetek i poetów do zajęcia postawy naiwnego dziecka, które testuje w obecności dorosłych (uosabiających regułę, prawo, obowiązek) nowe układy znaczeń, rozsadzające dotychczasowy porządek. Jednocześnie autorka Post-koiné... rzuca wyzwanie tym, którzy twierdzą, że umierają ludzie, a zdychają zwierzęta i robi to w sposób, który przekracza ramy kostycznego stylu akademickiego.

\section{Bibliografia}

Agamben G.: Co zostaje z Auschwitz. Archiwum i świadek. Przeł. S. Królak. Warszawa 2008.

Baratay É.: Zwierzęcy punkt widzenia. Inna wersja historii. Przeł. P. Tarasewicz. Gdańsk 2014.

Baratay É.: Zwierzęta w okopach. Zapomniane historie. Przeł. B. Brzezicka. Gdańsk 2017.

BARCz A.: Realizm ekologiczny. Od ekokrytyki do zookrytyki w literaturze polskiej. Katowice 2016.

BARgielska J.: Szybko przez wszystko. Wrocław 2013.

Bielska M.: Torfowy ogród z mostem i tygrysem. Poznań 2019.

Braidotti R.: Po człowieku. Przeł. J. Bednarek, A. Kowalczyk. Warszawa 2014.

Czapliński P.: Literatura i życie. Perspektywy biopoetyki. W: Teoria-literatura-życie.

Praktykowanie teorii w humanistyce współczesnej. Red. R. Nycz, A. LegeżyńsKA. Warszawa 2012, s. 63-93.

Dalej niż gender. Ludzie i inne zwierzęta. https://www.gosc.pl/doc/1874121.Dalejniz-gender-Ludzie-i-inne-zwierzeta [dostęp: 26.07.2020].

Domańska E.: Nekros. Wprowadzenie do ontologii martwego ciała. Warszawa 2017.

Fiedorczuk J.: Cyborg w ogrodzie. Wprowadzenie do ekokrytyki. Gdańsk 2015.

Fiedorczuk J., Beltrán G.: Ekopoetyka. Ekologiczna obrona poezji. Warszawa 2015.

Filipowicz A.: (Prze)zwierzęcenia. Poetyckie drogi do postantropocentryzmu. Gdańsk 2017.

Foltz C.R.: Czy przyroda jest sprawcza w znaczeniu historycznym? Historia świata, historia środowiska oraz to, w jaki sposób historycy moga pomóc ocalić Ziemię. 
Przeł. A. Czarnacka. W: Teoria wiedzy o przeszłości na tle wspótczesnej humanistyki. Antologia. Red. E. Domańska. Poznań 2010, s. 631-659.

Galant A.: Polowania i linienia. Śmierć zwierzat w wybranej prozie kobiet. W: Twórczość niepozorna. Szkice o literaturze. Red. J. GrąDziel-Wójcik, A. Kwiatкowska, L. Marzec. Kraków 2015, s. 249-258.

Gzyra D.: Dziękuję za świńskie oczy. Jak krzywdzimy zwierzęta. Warszawa 2018.

GzYra D.: Zwierzęta $i$ ich studia. https://krytykapolityczna.pl/kraj/gzyra-zwierze ta-i-ich-studia/ [dostęp: 26.07.2020].

Haraway D.: Manifest gatunków stowarzyszonych. Przeł. J. Bednarek. W: Teorie wywrotowe. Antologia przekładów. Red. A. Gajewska. Poznań 2012, s. 241-260.

Hilberg R.: Sprawcy - ofiary - świadkowie. Zagłada Żydów 1933-1945. Przeł. J. GIEвUŁTOWSK. Warszawa 2007.

Jarzyna A.: Imaginauci. Pismo wyobraźni w poezji Bolesława Leśmiana, Józefa Czechowicza, Krzysztofa Kamila Baczyńskiego, Tadeusza Nowaka. Łódź-Kraków 2017.

Jarzyna A.: Post-koiné. Studia o nieantropocentrycznych językach (poetyckich). Łódź 2019.

Jarzyna A.: Pójście za Norwidem (w polskiej poezji wspótczesnej). Lublin 2013.

Котт J.: Powiastki dla wnuczek. Warszawa 2002.

Kramkowska-Dąвrowska A.: Krasiński. Świadectwo. Łódź 2020.

KRupiński P.: Dlaczego gessi krzyczały? Zwierzęta i Zagłada w literaturze polskiej XX $i$ XXI wieku. Warszawa 2016.

Leоciak J.: "jak owce na rzeź" - figura Zagłady. W: Literatura polska wobec Zagłady (1939-1968). Red. S. Buryła, D. Krawczyńska, J. Leociak. Warszawa 2012, s. $159-165$.

ŁubiEŃski S.: Książka o śmieciach. Warszawa 2020.

Łukasiewicz J.: Poeta Grochowiak. Wrocław 2019.

Мүтүсн-Forajter B.: Czułe punkty Grochowiaka. Szkice i interpretacje. Katowice 2010.

Poetyki ekocydu. Historia - natura - konflikt. Red. A. Ubertowska, D. KorczyńsKa-PARtyka, E. Kuliś. Warszawa 2019.

Sontag S.: Widok cudzego cierpienia. Przeł. S. Magala. Kraków 2010.

Spowiedź wyobraźni (szkice i rozmowy). Wybór, wstęp A. JARzyna. Kraków 2014.

TAвоRsKa A.: Spiskowcy wyobraźni. Gdańsk 2013.

Ubertowska A.: Historie biotyczne. Pomiędzy estetyka a geotrauma. Warszawa 2020.

UвеRтошsка A.: "Kamienie niepokoja się i staja się agresywne”. Holokaust w świetle ekokrytyki. „Poznańskie Studia Polonistyczne. Seria Literacka” 2015, nr 25, s. 93-111.

Ubertowska A.: Natura u kresu (ekocyd). Podmiotowość po katastrofie. „Teksty Drugie" 2013, nr 1-2, s. 33-44.

Zwierzęta $i$ ich ludzie. Zmierzch antropocentrycznego paradygmatu. Red. A. BARCz, D. ŁAGODZKa. Warszawa 2015.

Zwierzęta i ludzie. Red. J. KureK, K. Maliszewski. Chorzów 2011. 
Andrzej Juchniewicz - doktorant literaturoznawstwa w Szkole Doktorskiej Uniwersytetu Śląskiego w Katowicach. Zajmuje się poezją polską drugiej połowy XX wieku, problematyką żydowską w literaturze polskiej oraz związkami wyobraźni z Zagładą. Obecnie bada narracje, w których krzyżują się losy zwierząt i ludzi w sytuacjach granicznych (podczas wojen i kataklizmów), a także archiwum i spuściznę literacką i plastyczną Erny Rosenstein. Współpracuje z „Nowymi Książkami”, „Śląskiem”, „Znakiem”. Publikował w „Tekstach Drugich”, „Narracjach o Zagładzie”, „Postscriptum Polonistycznym”, „Śląskich Studiach Polonistycznych", "Czytaniu Literatury. Łódzkich Studiach Literaturoznawczych”, „Wielogłosie”, „Opcjach”, „Masce” i „Wizjach”. Obronił prace dyplomową pt. Poetyki Zagłady. Przemoc - afekt - wyobraźnia pod kierunkiem prof. zw. dr. hab. Mariana Kisiela. Stypendysta Rektora Uniwersytetu Śląskiego dla najlepszych studentów w roku akademickim 2018/2019.

e-mail: andrzejjuchniewicz@o2.pl 
